\title{
An imaginary legal conundrum: A reply to the response by Mahomed, Nöthling-Slabbert and Pepper
}

\author{
D W Jordaan, $\mathrm{PhD}$ \\ School of Law, Howard College, University of KwaZulu-Natal, Durban
}

Corresponding author: D W Jordaan (jordaand@ukzn.ac.za)

\begin{abstract}
In their original article on the subject of research using human biological material, Mahomed, Nöthling-Slabbert and Pepper advanced the notion that the law regarding ownership of human biological material is uncertain, and proposed that our country's healthcare policy of altruism be changed to mandatory profit-sharing by research participants. In my critique article, I took issue with the notion that the relevant law is uncertain, and suggested that Mahomed et al. failed to present a convincing argument in support of the proposed policy change from altruism to profit-sharing. In their response to my critique article, Mahomed et al. persist with the notion that the relevant law is uncertain; I suggest that this notion is erroneous, as our common law in this regard is well established, and as the authors base their argument exclusively on foreign case law. The authors further fail to make use of the opportunity to augment their argument in support of their proposed policy change from altruism to profit-sharing - in fact, they contradict themselves by disavowing their proposed policy change.
\end{abstract}

S Afr Med J 2017;107(3):199-200. DOI:10.7196/SAMJ.2017.v107i3.12337

I am disappointed by the aggressive tone adopted by Mahomed, Nöthling-Slabbert and Pepper in their letter to the editor ${ }^{[1]}$ and in their response article. ${ }^{[2]} \mathrm{I}$ am also disappointed that they make a number of vague allegations against me, such as that I misinterpret the issues, and that my conclusions are not reasonable, without substantiating these allegations with any specific examples. Suffice it to say that there is no merit in these vague allegations. The reader is invited to read the original article by Mahomed et al. ${ }^{[3]}$ and my critique article,${ }^{[4]}$ and to be the judge.

In this response, I will briefly address the following main themes: (i) the issue of ownership of human biological material; (ii) profitsharing by research participants; and (iii) terminology.

\section{The issue of ownership of human biological material}

Our law provides that human biological material cannot be owned, ${ }^{[5,6]}$ with the exception of gametes and embryos in vitro. ${ }^{[7]}$ However, Mahomed et al. persist in their argument that there are no firm rules, and that each situation will have to be determined on its own facts. In support of their argument that there is uncertainty regarding ownership of human biological material, Mahomed et al. in their response article refer extensively to foreign case law. However, cases in foreign jurisdictions do not change South African (SA) law, or make SA law uncertain. Accordingly, the argument made by Mahomed et al. that there is uncertainty regarding ownership of human biological material, and that such uncertainty calls for legislative amendment, does not hold water.

Ownership is a species of proprietary rights. In both their original article and their response article, Mahomed et al. use the concept 'proprietary right' interchangeably with 'proprietary interest'. This is incorrect and confusing, as a 'right' is not the same as an 'interest' in our law. In their original article, Mahomed et al. propose the following definition of 'proprietary rights': 'Proprietary rights are property rights of an owner of proprietary information that may be protected under law.' In a footnote reference, they rely on BusinessDictionary.com as the source of this definition of 'proprietary rights'. The BusinessDictionary.com definition is manifestly incorrect. In our law, proprietary rights encompass not only rights that have information as object, but a whole array of rights that have a patrimonial element, such as personal rights to performance in terms of a contract, and real rights in tangible objects.

In their response article, Mahomed et al. express the opinion that there is 'confusion' among 'researchers and academics working in the field' regarding ownership of human biological material and a series of other legal concepts. The two sources cited for such purported 'confusion' are articles co-authored by inter alia Pepper and NöthlingSlabbert on the application of the concept 'genomic sovereignty' to human biological material. In this context, Pepper and NöthlingSlabbert indeed express the opinion that there is confusion in the law. However, self-referencing to one's own opinion regarding the state of the law cannot logically be generalised to 'confusion' among 'researchers and academics working in the field'.

Profit-sharing by research participants Our law upholds an altruistic paradigm for participation in research and outlaws any form of remuneration of the research participant over and above reimbursement for reasonable expenses. ${ }^{[8]}$ In their original article, Mahomed et al. clearly challenge the altruistic paradigm and propose profit-sharing by research participants. For instance, they state as follows: 'This [a proprietary interest vested in the research participant] would ensure that the proceeds of any therapy developed from the tissues [biological material] would be distributed, in part, to the subject [research participant]. A mandatory agreement stipulating the terms and conditions of such distribution should be required.' (My emphases.)

I concluded my critique article by suggesting that there is a broad array of ethical and legal ramifications that must be considered if the altruistic paradigm is to be replaced with a new paradigm of benefit- 
sharing (which includes profit-sharing) by research participants. Despite having the opportunity to respond, Mahomed et al. failed to address any of these ethical and legal ramifications. In my critique article, I also highlighted the absence of a convincing rationale for replacing the altruistic paradigm with a paradigm of benefit-sharing. Again, despite having the opportunity to respond, Mahomed et al. failed to attempt to make a case for the paradigm change that they advocate in their original article.

Instead of picking up the gauntlet and defending their proposal of profit-sharing, Mahomed et al. attempt to avoid the issue by denying that they proposed that the current altruistic paradigm be replaced with profit-sharing by research participants. However, paradoxically, in the same paragraph of their response article they propose that research participants be afforded a 'proprietary interest' in the human biological material that they contribute to research, in order to ensure that the 'proceeds' of any therapy that is developed through such research would be 'distributed, in part, to the participants'. The distribution of proceeds from commercial research to research participants is plainly a mode of profit-sharing, and a clear departure from the altruistic paradigm of SA's current healthcare policy. Yet, again paradoxically, Mahomed et al. in their response article maintain that it was never their intention to challenge current healthcare policy. These self-contradictory avoidance attempts employed by Mahomed et al. frustrate proper discourse on the subject.

Lastly, Mahomed et al. still fail to give an accurate representation of Truog et al. ${ }^{[9]}$ In their original article, they state that 'Truog et al. have suggested that there are three distinct obligations that an investigator who seeks access to tissue might have towards an individual whose tissues, upon removal from the body, might have value for biomedical research. These include ... rights to revenue streams.' (My emphases.) In their response article, Mahomed et al. state as follows: 'The fact that Truog et al. do not specifically advocate a profit-sharing model is not a point that the authors of the original article were trying to make.' In fact, Truog et al. ${ }^{[9]}$ specifically argue against profit-sharing by research participants. The reader is invited to read the comprehensive arguments by Truog et al. against profit-sharing.

\section{Terminology}

In their original article, Mahomed et al. use the terms 'donor' and 'subject'. In my critique article, I suggested that the term 'research participant' is preferable to 'donor', given that 'donor' has a legaltechnical meaning that implies ownership; in contrast, the term 'research participant' is not shackled by a similar implication, and is sufficiently broad to include participation in activities that go beyond allowing biological material to be withdrawn and used in research, but that are also integral to the research project. In their response article, Mahomed et al. appear to adopt my suggestion of rather employing the term 'participant'.
The definition of 'research participant' that I proposed in my critique article is based on the first edition of the health ethics guidelines ${ }^{[10]}$ by the Department of Health. In their response article, Mahomed et al. point out that a second edition of the health ethics guidelines ${ }^{[11]}$ has since been published, and express the opinion that my reference to the first edition's definition is incorrect. While a second edition of the health ethics guidelines has indeed been published, it uses the terms 'donor' and 'research participant' interchangeably, and fails to provide a definition of 'research participant'. Given this omission in the second edition, I suggest that it is reasonable to rely on the definition provided in the first edition, as I did. Accordingly, there is no merit in the opinion of Mahomed et al. that my reference to the first edition's definition is 'incorrect'. They fail to provide any detail as to why they take issue with the definition of 'research participant' that I proposed.

\section{Conclusion}

Social justice in the context of research using human biological material is an important contemporary legal-ethical issue. The stated purpose of my critique article was to stimulate debate on this important issue. Academic discourse on this issue would have been assisted had Mahomed et al. in their response article attempted to appreciate and answer the main points that I made in my critique article. Rather, they attacked my critique article with vague rhetoric and contradicted themselves in an attempt to avoid defending their proposal of profit-sharing. Furthermore, they persisted with legal errors, and relied on self-referencing to aver 'confusion' about ownership of human biological material where there are in fact wellestablished rules. Accordingly, I suggest that the 'legal conundrum' regarding the ownership of human biological material that Mahomed et al. proclaim is sensationalist and not real.

\footnotetext{
1. Mahomed S, Nöthling-Slabbert M, Pepper MS. Social justice and research using human biological material: A right to respond. S Afr Med J 2016;106(9):841-841. http://dx.doi.org/10.7196/SAMJ.2016. v106i9.11379

2. Mahomed S, Nöthling-Slabbert M, Pepper MS. Ownership and human tissue - the legal conundrum: A response to Jordaan's critique. S Afr Med J 2017;107(3):196-198. http://dx.doi.org/10.7196/ SAMI.2017.v107i3.12062

3. Mahomed S, Nöthling-Slabbert M, Pepper MS. The legal position on the classification of human tissue in South Africa: Can tissues be owned? S Afr J Bioethics Law 2013;6(1):16-20. http://dx.doi. org/10.7196/SAJBL.258

org/10.7196/SAJBL.258
4. Jordaan DW. Social justice and research using human biological material: A response to Mahomed, 4. Jordaan DW. Social justice and research using human biological material: A response to Mahomed,
Nöthling-Slabbert and Pepper. S Afr Med J 2016;106(7):678-680. http://dx.doi.org/10.7196/SAMJ.2016. v106i7.10552.

5. Grotius. Inleidinge tot de Hollandsche Rechts-Geleerdheid. 2.1.3.

6. Digesta 9.2 .13 pr.

7. South Africa. National Health Act 61 of 2003. Regulations: Relating to Artificial Fertilisation of Persons. Government Gazette No. 35099, 2012 (published under Government Notice R175).

8. South Africa. National Health Act 61 of 2003. Regulations: Relating to the use of Human Biological Material. Government Gazette No. 35099, 2012 (published under Government Notice R177).

Truog RD, Kesselheim AS, Joffe S. Paying tissue donors: The legacy of Henrietta Lacks. Science 2012;337(6090):37-38. http//dx do. 0 r $/ 10.1126 /$ science. 1216888

10. National Department of Health, South Africa. Ethics in Health Research: Principles, Structures and Processes. Pretorian of Health,

11. National Department of Health, South Africa. Ethics in Health Research: Principles, Processes and National Department of Health,
Structures. Pretoria: NDoH, 2015 .
}

Accepted 23 January 2017 